\title{
Facultatively Anaerobic Bacteria Showing High Productivities of 2,5-Diketo-D-gluconate from D-Glucose
}

\author{
Takayasu Sonoyama, Shigeo Yagi and Bunji Kageyama \\ Biotechnology Development, Department of Production, Shionogi \& Co., Ltd., \\ 2-1-3, Kuise-terajima, Amagasaki, Hyogo 660, Japan \\ Received August 28, 1987
}

\begin{abstract}
Forty-two bacterial strains that produce calcium 2,5-diketo-D-gluconate from $30 \%(\mathrm{w} / \mathrm{v}) \mathrm{D}$ glucose with yields of more than $70 \mathrm{~mol} \%$ were isolated from various soil and fruit samples. They were small rod-shaped, gram-negative, non-spore-forming and facultatively anaerobic bacteria, and could be classified taxonomically into three groups. Representative strains (SHS 2003, ATCC 31623; SHS 2006, ATCC 31626; SHS 2008, ATCC 31628) of the latter were identified as members of the genus Erwinia. The DNA base ratios of these strains ranged from 46.3 to $48.7 \mathrm{~mol} \%$ guanine plus cytosine.

The results of experiments using whole cells and cell extracts of these three strains suggested that D-glucose is oxidized to 2,5-diketo-D-gluconate via D-gluconate and 2-keto-D-gluconate. No 5keto-D-gluconate was detected in the culture broth throughout their cultivation. Most activities of enzyme(s) responsible for the oxidation of D-glucose to 2,5-diketo-D-gluconate were found in the particulate fractions of these strains.
\end{abstract}

Calcium 2,5-diketo-D-gluconate (Ca$25 \mathrm{DKG}$; the free acid being referred to as $25 \mathrm{DKG}$ herein) is biochemically converted to calcium 2-keto-L-gulonate, ${ }^{1)}$ which is a key intermediate in vitamin $\mathrm{C}$ synthesis. ${ }^{2)}$

Since Katznelson et al. ${ }^{3)}$ first prepared and identified $25 \mathrm{DKG}$ as a fermentation product of Acetobacter melanogenus, the ability of microorganisms to produce $25 \mathrm{DKG}$ from D-glucose has been reported for aerobic bacteria, i.e., several strains of Acetobacter ${ }^{2} 4$ ) and Gluconobacter, ${ }^{5)}$ and Acetomonas albosesamae $^{6)}$ (Pseudomonas albosesamae Wakisaka $\left.1964^{7)}\right)$. A strain of $A$. albosesamae has effectively produced $\mathrm{Ca}-25 \mathrm{DKG}$ from $\mathrm{D}$-glucose. This strain, however, could not tolerate concentrations of D-glucose higher than $20 \%(w / v)$ and required a fermentation time of about $60 \mathrm{hr}$. 25DKG is unstable, especially as to heat and alkaline conditions. ${ }^{3)}$ A short fermentation time is important for preventing the decomposition of $25 \mathrm{DKG}$ produced. Because of this, we searched for the most efficient strains, as to $\mathrm{Ca}-25 \mathrm{DKG}$ production, found in nature. Consequently, we isolated 42 strains that produced Ca-25DKG from $30 \%$ (w/v) Dglucose with excellent yields, i.e., of more than $70 \mathrm{~mol} \%$, within $40 \mathrm{hr}$ in $1-1$ fermentors. All these isolates were facultatively anaerobic bacteria and were classified into the genus Erwinia. One of them was further improved through mutagenic treatment, finally producing $328.6 \mathrm{mg}$ of $\mathrm{Ca}-25 \mathrm{DKG}$ per $\mathrm{ml}$ with a $94.5 \mathrm{~mol} \%$ yield from D-glucose on 26 -hr cultivation, as reported previously. ${ }^{1)}$

This paper describes a taxonomic survey of the facultatively anaerobic isolates showing such high productivities of Ca-25DKG from D-glucose, and their metabolic pathway for $25 \mathrm{DKG}$ production.

\section{MATERIALS AND METHODS}

Chemicals. Ca-25DKG and calcium 5-keto-D-gluconate were prepared by the methods previously described. ${ }^{1)}$ Calcium 2-keto-D-gluconate and sodium D-gluconate were purchased from Nakarai Chemicals Ltd. (Kyoto, Japan). Other chemicals used for analyses were of reagent grade. All components of the media used were commercial 
preparations, unless otherwise noted.

Isolation and cultivation of 25DKG-producing strains. Soil, fruit and vegetable samples were dispersed in sterile water, respectively, and then plated onto medium $\mathrm{A}$, which contained $1 \mathrm{~g}$ of D-glucose; $0.1 \mathrm{~g}$ of yeast extract (Difco Laboratories, Detroit, Mich.), $0.1 \mathrm{~g}$ of peptone (Difco), $0.1 \mathrm{~g}$ of $\mathrm{KH}_{2} \mathrm{PO}_{4}, 0.02 \mathrm{~g}$ of $\mathrm{MgSO}_{4} \cdot 7 \mathrm{H}_{2} \mathrm{O}, 0.7 \mathrm{~g}$ of $\mathrm{CaCO}_{3}$ and $2 \mathrm{~g}$ of agar in $100 \mathrm{ml}$ of tap water. The colonies with clear zones around them due to the dissolution of $\mathrm{CaCO}_{3}$ were isolated and transferred to stock slants (GYP slants), which contained $0.5 \mathrm{~g}$ of glycerol, $0.5 \mathrm{~g}$ of yeast extract (Difco), $0.3 \mathrm{~g}$ of peptone (Difco), $0.1 \mathrm{~g}$ of $\mathrm{KH}_{2} \mathrm{PO}_{4}$, $0.02 \mathrm{~g}$ of $\mathrm{MgSO}_{4} \cdot 7 \mathrm{H}_{2} \mathrm{O}$ and $2 \mathrm{~g}$ of agar in $100 \mathrm{ml}$ of tap water. The isolates grown on GYP slants were streaked onto agar plates of medium $\mathrm{B}$, which contained $10 \mathrm{~g}$ of $\mathrm{D}$ glucose, $1.5 \mathrm{~g}$ of corn steep liquor, $0.1 \mathrm{~g}$ of $\mathrm{KH}_{2} \mathrm{PO}_{4}, 0.05 \mathrm{~g}$ of $\mathrm{MgSO}_{4} \cdot 7 \mathrm{H}_{2} \mathrm{O}, 2.9 \mathrm{~g}$ of $\mathrm{CaCO}_{3}$ and $2 \mathrm{~g}$ of agar in $100 \mathrm{ml}$ of tap water. The pHs of media $\mathrm{A}, \mathrm{B}$ and GYP were adjusted to 7.0 before sterilization at $121^{\circ} \mathrm{C}$ for $20 \mathrm{~min}$. Each of the strains grown on medium $\mathrm{B}$ agar plates was then inoculated with a loop of cells taken from a stock slant into medium $\mathrm{C}$ ( $50 \mathrm{ml}$ in a $500-\mathrm{ml}$ baffled flask), which contained $25 \mathrm{~g}$ of D-glucose, $1 \mathrm{~g}$ of corn steep liquor, $0.1 \mathrm{~g}$ of $\mathrm{KH}_{2} \mathrm{PO}_{4}, 0.05 \mathrm{~g}$ of $\mathrm{MgSO}_{4} \cdot 7 \mathrm{H}_{2} \mathrm{O}$ and $7.2 \mathrm{~g}$ of $\mathrm{CaCO}_{3}$ in $100 \mathrm{ml}$ of tap water, and then incubated at $28^{\circ} \mathrm{C}$ for $48 \mathrm{hr}$ on a rotary shaker at $250 \mathrm{rpm}$. The $\mathrm{pH}$ of medium $\mathrm{C}$ was adjusted to 7.0 before sterilization at $121^{\circ} \mathrm{C}$ for $20 \mathrm{~min}$. Each of the $25 \mathrm{DKG}$-producing strains that was confirmed to produce $\mathrm{Ca}-25 \mathrm{DKG}$ in medium $\mathrm{C}$ as described under Analytical methods was inoculated again from a GYP slant culture into the seed medium ( $50 \mathrm{ml}$ in a $500-\mathrm{ml}$ flask), which contained $1 \mathrm{~g}$ of D-glucose, $5 \mathrm{~g}$ of corn steep liquor, $0.1 \mathrm{~g}$ of $\mathrm{KH}_{2} \mathrm{PO}_{4}, 0.02 \mathrm{~g}$ of $\mathrm{MgSO}_{4} \cdot 7 \mathrm{H}_{2} \mathrm{O}, 0.1 \mathrm{~g}$ of $\mathrm{NaCl}$ and $0.5 \mathrm{~g}$ of $\mathrm{CaCO}_{3}$ in $100 \mathrm{ml}$ of tap water. The seed culture was shaken at $28^{\circ} \mathrm{C}$ for $14 \mathrm{hr}$ on a rotary shaker at $250 \mathrm{rpm}$.

The fermentor medium (medium D) contained $11.8 \mathrm{~g}$ of D-glucose, $3.5 \mathrm{~g}$ of corn steep liquor, $0.12 \mathrm{~g}$ of $\mathrm{KH}_{2} \mathrm{PO}_{4}$ and $9.7 \mathrm{~g}$ of $\mathrm{CaCO}_{3}$ in $100 \mathrm{ml}$ of tap water. Each $1-1$ fermentor $(280 \mathrm{ml}$ of medium D) was inoculated with $50 \mathrm{ml}$ of a seed culture, followed by incubation at $28^{\circ} \mathrm{C}$ with an air flow rate of $1 \mathrm{vvm}$ and agitation at $1760 \mathrm{rpm}$. A sterile solution of $50 \%$ (w/w) D-glucose was fed twice to the culture as described under Results. Each fermentation was continued for $49 \mathrm{hr}$. The $\mathrm{pHs}$ of the seed and fermentation media were adjusted to 7.0 before sterilization at $121^{\circ} \mathrm{C}$ for $20 \mathrm{~min}$. Becterial growth was measured as the change in optical density at $660 \mathrm{~nm}$ with a Hitachi spectrophotometer, model 139.

Analytical methods. D-Glucose, D-gluconate, 2-keto-Dgluconate, 25DKG and 5-keto-D-gluconate were identified by paper chromatography, according to the method described by Wakisaka, ${ }^{8)}$ and also by gas chromatography. ${ }^{1}$ The concentrations of Ca-25DKG and calcium 2-keto-D- gluconate were determined by the $\mathrm{NH}_{4} \mathrm{OH}-\mathrm{HCl}$ method as described previously. ${ }^{1 /}$ D-Glucose was measured enzymatically by the method of Mollering and Bergmeyer. ${ }^{9)}$ D-Glucose was also determined enzymatically by the Glucose-B-Test (Wako Pure Chemical Industries Ltd., Osaka, Japan).

Identification procedures. 25DKG-Producing strains were taxonomically characterized by conventional methods for morphological, biochemical and physiological properties. ${ }^{10 \sim 13)}$ Morphological characteristics were observed over a period of $24 \mathrm{hr}$ for cultures grown on bouillon agar and mannitol agar ${ }^{14 /}$ at $28^{\circ} \mathrm{C}$. Flagellation was observed electron-microscopically by the method of Hillier et al. ${ }^{15)}$ with a Nihon Densi transmission electron microscope, model JEM 100B. Anaerobic growth of $25 \mathrm{DKG}$-producing strains on GYP agar plates and mannitol agar plates ${ }^{14)}$ was examined at $28^{\circ} \mathrm{C}$ for $72 \mathrm{hr}$ in a Gas-pack anaerobic system (BBL. Dickson \& Co., Cockeysville, U.S.A.) with Pseudomonas aeruginosa and Escherichia coli as controls. The utilization of oraganic compounds, production of reducing substances from sucrose, $\mathrm{NaCl}$ tolerance, and hydrolysis of casein and cotton seed oil were examined by the methods of Dye. ${ }^{16)}$ The decarboxylation of amino acids was examined by the method of Shaw and Clark. ${ }^{17)}$ Pigment production and mucoid growth were observed under the conditions described by Lelliott and Dickey. ${ }^{18)}$ Pectate degradation and deoxyribonuclease (DNase) activity were examined on Paton's pectate gel medium ${ }^{19)}$ and Bacto DNase agar (Difco), respectively. Ubiquinone was extracted and determined by the method described by Yamada et $a l^{20)}$ The guanine plus cytosine $(\mathrm{G}+\mathrm{C})$ content of the deoxyribonucleic acid was estimated from the thermal denaturation temperature (Tm) and the buoyant density in $\mathrm{CsCl}$ by the methods of Marmur and Doty, ${ }^{21)}$ and Schidraut et al., ${ }^{22}$ respectively.

Preparation of cell extracts, soluble fractions and particulate fractions. Cell were grown aerobically at $28^{\circ} \mathrm{C}$ for $6 \mathrm{hr}$ in a medium containing $5 \mathrm{~g}$ of D-glucose, $0.5 \mathrm{~g}$ of peptone (Difco), $0.5 \mathrm{~g}$ of yeast extract (Difco) and $2.0 \mathrm{~g}$ of $\mathrm{CaCO}_{3}$ in $100 \mathrm{ml}$ of tap water. Cells were harvested by centrifugation $\left(12,000 \times g\right.$ for $10 \mathrm{~min}$ at $\left.4^{\circ} \mathrm{C}\right)$ and then washed twice with $0.1 \mathrm{M}$ phosphate buffer $(\mathrm{pH} 6.0$ ). The cell paste was suspended in the same fresh buffer and then disrupted by passage through a French pressure cell press at $1500 \mathrm{~kg} / \mathrm{cm}^{2}$. Cell debris and unbroken cells were removed by centrifugation $(15,000 \times g$ for $10 \mathrm{~min}$ at $4 \mathrm{C}$ ). The resulting cell extract was further centrifuged $\left(156,000 \times g\right.$ for $120 \mathrm{~min}$ at $\left.4^{\circ} \mathrm{C}\right)$, which yielded particulate and soluble fractions. The particulate material was resuspended in fresh $0.1 \mathrm{M}$ phosphate buffer $(\mathrm{pH} \mathrm{6.0)}$. The soluble fraction used for the product analyses was dialyzed overnight at about $4^{\circ} \mathrm{C}$ against $0.05 \mathrm{M}$ phosphate buffer (pH 7.0). 
Reaction products of $\mathrm{D}-$ glucose, D-gluconate, 2-keto-Dgluconate and 5-keto-D-gluconate with the cell extracts. Reaction products were measured with two reaction mixtures, I and II. Reaction mixture I consisted of $10 \mu \mathrm{mol}$ of substrate, $50 \mu \mathrm{mol}$ of 2,6-dichlorophenolindophenol (DCPIP), $20 \mu \mathrm{mol}$ of phenazine methosulfate (PMS), $150 \mu \mathrm{mol}$ of phosphate (pH 6.0) and the cell extract $(0.5 \mathrm{mg}$ of protein) in a total volume of $3.0 \mathrm{ml}$. Reaction mixture II contained $50 \mu \mathrm{mol}$ of substrate, $50 \mu \mathrm{mol}$ of $\mathrm{NAD}(\mathrm{P})^{+}, 2.5 \mu \mathrm{mol}$ of $\mathrm{KCN}, 125 \mu \mathrm{mol}$ of phosphate $(\mathrm{pH}$ $7.0)$ and the dialyzed soluble soluble fraction $(10 \sim 12 \mathrm{mg}$ of protein) in a total volume of $2.5 \mathrm{ml}$. The reaction was started by adding the substrate and then the mixture was allowed to stand at $28^{\circ} \mathrm{C}$. The reaction time was $30 \mathrm{~min}$ for mixture I and $2 \mathrm{hr}$ for mixture II, respectively. The reaction products were determined by the methods described under Analytical methods.

Enzyme assays. The reaction mixture contained $0.5 \mu \mathrm{mol}$ of 2,6-dichlorophenolindophenol, $0.2 \mu \mathrm{mol}$ of phenazine methosulfate, $100 \mu \mathrm{mol}$ of substrate (D-glucose, sodium D-gluconate or sodium 2-keto-D-gluconate), $100 \mu \mathrm{mol}$ of phosphate $(\mathrm{pH} 6.0)$ and the soluble or particulate fraction in a total volume of $3.0 \mathrm{ml}$. Enzyme activities were assayed spectrophotometrically at $600 \mathrm{~nm}$ with a Hitachi spectrophotometer, model 200-10.

One unit of enzyme activities was defined as the amount of enzyme that reduced $1 \mu \mathrm{mol}$ of 2,6-dichlorophenolindophenol per minute at $28^{\circ} \mathrm{C}$. The extinction coefficient of 2,6-dichlorophenolindophenol was $11 \mathrm{mM}^{-1} \cdot \mathrm{cm}^{-1}$ at $\mathrm{pH}$ 6.0. Protein concentrations were determined by the method of Lowry et al. ${ }^{23)}$ with bovine serum albumin as standard.

\section{RESULTS}

\section{Isolation of $25 \mathrm{DKG}$-producing strains}

After a suitable incubation time of 2 to 4 days, 369 strains of acid-forming bacteria were first isolated from 235 soil, vegetable and fruit samples on agar plates containing $1 \%(\mathrm{w} / \mathrm{v})$ D-glucose (medium A). Acid formation was confirmed by the appearance of clear zones around the growing colonies on the agar plates containing $\mathrm{CaCO}_{3}$. The ability of these isolates to tolerate high sugar concentrations was tested on agar plates containing $10 \%(\mathrm{w} / \mathrm{v}) \mathrm{D}$ glucose (medium B). Then, the 203 strains that grew on the above agar plates (medium B) were cultivated in baffled flasks containing $25 \%(\mathrm{w} / \mathrm{v})$ D-glucose (medium C), and 96 strains were confirmed to have accumulated more or less Ca-25DKG in the final broth by paper chromatography.
The Ca-25DKG productivity of each of the 96 strains thus selected was further tested in a 1-1 fermemtor containing medium D. At 6-hr and 12-hr cultivation, 99 and $165 \mathrm{~g}$ of a sterile solution of $50 \%(\mathrm{w} / \mathrm{w})$ D-glucose were fed to the culture, respectively. The total amounts of D-glucose added to the culture were equivalent to $30 \%(\mathrm{w} / \mathrm{v})$ of the initital concentration in the medium $D$. Under these conditions, 42 strains could convert D-glucose to $\mathrm{Ca}-25 \mathrm{DKG}$ with yields of more than 70 mol $\%$ within $40-\mathrm{hr}$ cultivation. After $30-\mathrm{hr}$ cultivation, three representative strains, SHS 2003, SHS 2006 and SHS 2008, had accumulated $278 \mathrm{mg}, 285 \mathrm{mg}$ and $256 \mathrm{mg}$ of Ca$25 \mathrm{DKG}$ per $\mathrm{ml}$, respectively. The yields of $25 \mathrm{DKG}$ from D-glucose were $76 \mathrm{~mol} \%$ for strain SHS 2003, $78 \mathrm{~mol}_{\%}^{\circ}$ for strain SHS 2006 and $70 \mathrm{~mol}^{\%}$ for strain 2008 , respectively. In the culture broth of all 42 strains, the formation of calcium D-gluconate and calcium 2keto-D-gluconate, as intermediates, was detected on paper chromatography, whereas no calcium 5-keto-D-gluconate was detected throughout their cultivation.

\section{Taxonomic studies on the 25DKG-producing strains}

All the 42 strains that showed high Ca$25 \mathrm{DKG}$ productivities were small $(0.8$ to 1.5 by 1.0 to $3.3 \mu \mathrm{m}$ in size), gram-negative, nonspore-forming and facultatively anaerobic bacteria, occurring singly or in pairs. They grew weakly in a Gas-pack system and paraffin-stab cultures. On the basis of the results of various taxonomical tests, the 42 strains were classified into three groups, represented by strains SHS 2003, SHS 2006 and SHS 2008. The differences in taxonomical properties among the three groups were mainly in cell size, motility, decarboxylation of glutamate, reaction on litmus milk, production of reduced compounds from sucrose, Voges-Proskauer reaction, acid production from mannitol, glycerol, lactose and sucrose, utilization of acetate and lactate, $\mathrm{G}+\mathrm{C}$ content, ubiquinone, temperature for growth, and $\mathrm{pH}$ for growth (Table I). The common charac- 
Table I. Taxonomical Differences among the Three Representative Strains, SHS 2003, SHS 2006 AND SHS 2008

\begin{tabular}{|c|c|c|c|}
\hline Parameters & $\begin{array}{c}\text { SHS } 2003 \\
\text { (ATCC 31623) }\end{array}$ & $\begin{array}{c}\text { SHS } 2006 \\
\text { (ATCC } 31626 \text { ) }\end{array}$ & $\begin{array}{c}\text { SHS } 2008 \\
\text { (ATCC 31628) }\end{array}$ \\
\hline \multicolumn{4}{|l|}{ Cell size $(\mu \mathrm{m})$ : } \\
\hline Diameter & $0.8 \sim 1.2$ & $1.1 \sim 1.3$ & $0.8 \sim 0.9$ \\
\hline Length & $1.0 \sim 2.9$ & $1.3 \sim 1.9$ & $1.5 \sim 1.7$ \\
\hline Motility & - & - & + \\
\hline Flagella & None & None & Lateral \\
\hline Ubiquinone & 8 and 7 & 8 & 8 and 7 \\
\hline $\begin{array}{l}\text { Acidification and coagulation } \\
\text { of Litmus milk }\end{array}$ & + & - & - \\
\hline Decarboxylation of L-glutamate & - & + & - \\
\hline Hydrolysis of lactose & + & - & - \\
\hline Voges-Proskauer reaction & $\mathrm{w}$ & w & + \\
\hline $\begin{array}{l}\text { Production of reducing compounds } \\
\text { from sucrose }\end{array}$ & - & + & + \\
\hline Temperature for growth $\left({ }^{\circ} \mathrm{C}\right)$ & $8 \sim 39$ & $6 \sim 39$ & $8 \sim 40$ \\
\hline Temperature for optimum growth $\left({ }^{\circ} \mathrm{C}\right)$ & $18 \sim 31$ & $21 \sim 28$ & $20 \sim 33$ \\
\hline $\mathrm{pH}$ for growth & $5.5 \sim 8.0$ & $5.5 \sim 8.5$ & $5.5 \sim 7.5$ \\
\hline \multicolumn{4}{|l|}{ Acid production from: } \\
\hline Mannitol and lactose & + & - & - \\
\hline Glycerol & + & - & + \\
\hline Sucrose & - & + & + \\
\hline \multicolumn{4}{|l|}{ Utilization of: } \\
\hline Acetate and lactate & + & \pm & + \\
\hline \multicolumn{4}{|l|}{$\mathrm{G}+\mathrm{C}$ contents $(\mathrm{mol} \%)$} \\
\hline Bouyant density & 45.8 & 47.8 & 49.1 \\
\hline$T_{\mathrm{m}}$ & 46.3 & 48.5 & 48.7 \\
\hline Origin & Mandarin orange & Mandarin orange & Soil \\
\hline
\end{tabular}

Symbols and abbreviations: + , positive; - , negative; \pm , negative or slightly positive; w, weakly positive.

teristics of the three representative strains are as follows: oxidation-fermentation test, facultative; methylene blue reduction, positive; catalase, positive; oxidase, negative; $\mathrm{KCN}$ inhibition, positive; nitrite produced from nitrate; nitrate respiration, negative; urease not produced; casein not hydrolyzed; gelatin not liquefied; hydrogen sulfide not produced; ammonia not produced; decarboxylation of Llysine, L-arginine and L-ornithine, negative; starch not hydrolyzed; citrates utilized; methyl red test, positive; mucoid growth on sucrose medium observed; ethanol not oxidized to acetic acid; grew in $5 \% \mathrm{NaCl}$; nicotinamide required for growth; lipase, negative; cotton seed oil not hydrolyzed; pectate not degraded; deoxyribonuclease activity, negative; no formation of a blue, pink, yellow or fluorescent pigment; acid but no gas from fruc- tose, glucose, galactose, $\beta$-methyl glucoside, mannose, ribose, salicin, xylose, melibiose and cellobiose; no acid and no gas from maltose, dextrin, esculin, rhamnose, sorbitol, raffinose, adonitol, dulcitol, melezitose, arabinose, $\alpha$-methyl glucoside or inositol; citrate, formate, fumarate, gluconate, succinate and malate utilized; and benzoate, galacturonate, malonate, oxalate, propionate and tartrate not utilized.

The three representative strains, SHS 2003, SHS 2006 and SHS 2008, have many characters in common with species belonging to the family Enterobacteriaceae, as described by Brenner $^{24)}$ : small, gram-negative, motile (with lateral flagella or flagellum) or non-motile, and facultatively anaerobic rods; metabolism, respiratory and fermentative; catalase, positive; oxidase, negative; nitrite produced from ni- 
trate; and $\mathrm{G}+\mathrm{C}$ content, $38 \sim 60 \mathrm{~mol} \%$. In addition, they share some basic properties with species of the genus Erwinia, as described by Lelliott and Dickey ${ }^{18)}$ : acid production from $\beta$-methylglucoside and sucrose, positive (strain SHS 2003 did not produce acid from sucrose but utilized sucrose); acid production from adonitol, dulcitol and melezitose, rarely; benzoate, oxalate and propionate not utilized; gas production, comparatively weak or absent; starch not hydrolyzed; decarboxylase for glutamate, negative (strain SHS 2006 was positive); urease or lipase production, rarely; temperature for growth, below $40^{\circ} \mathrm{C}$. On the basis of the above similarities, we classified the three representative strains, SHS 2003, SHS 2006 and SHS 2008, as members of the genus Erwinia, although there, at present, seems to be several unsolved problems as to the taxonomy of the genus Erwina. ${ }^{19)}$ There is a distinct difference between our isolates and the known Erwinia species in the $\mathrm{G}+\mathrm{C}$ content, i.e., 46.3 to $48.7 \mathrm{~mol} \%$ for our isolates, as shown in Table $\mathrm{I}$, and 50 to $57 \mathrm{~mol} \%$ for the known Erwinia species. ${ }^{18\}}$ These three strains have been deposited at the ATCC under the number given in Table I.

\section{Reaction products in the cell extracts}

D-Glucose, D-gluconate, 2-keto-D-gluconate and 5-keto-D-gluconate were used as substrates. After $30-\mathrm{min}$ incubation at $28^{\circ} \mathrm{C}$, the products formed were determined. Despite the addition or non-addition of PMS plus DCPIP as electron acceptors, the cell extracts $(0.5 \mathrm{mg}$ of protein) prepared from all the above three representative strains, SHS 2003, SHS 2006 and SHS 2008, produced D-gluconate from Dglucose, 2-keto-D-gluconate from D-gluconate, and 25DKG from 2-keto-D-gluconate. The addition of PMS plus DCPIP stimulated the formation of each product. Table II summarized the results. The formation of $\mathrm{D}$ gluconate, 2-keto-D-gluconate and 25DKG from D-glucose was observed on increasing the amount of protein in the reaction mixture. No formation of 5-keto-D-gluconate from Dgluconate or $25 \mathrm{DKG}$ from 5-keto-D-gluconate was observed. When $\mathrm{NAD}^{+}$or $\mathrm{NADP}^{+}$was used instead of PMS plus DCPIP, 2-keto-D-

Table II. Products Formed from d-Glucose and Related Substances in Cell Extracts of tHe Representative Strains, SHS 2003, SHS 2006 AND SHS 2008, IDENTified by Paper and Gas Chromatography

\begin{tabular}{|c|c|c|c|c|c|c|}
\hline \multirow{2}{*}{ Strain } & \multirow{2}{*}{ Substrate $^{\alpha}$} & \multirow{2}{*}{$\begin{array}{l}\text { Electron } \\
\text { acceptors }^{b}\end{array}$} & \multicolumn{4}{|c|}{ Products detected $d^{a, c}$} \\
\hline & & & DGA & $2 \mathrm{KDG}$ & $5 \mathrm{KDG}$ & $25 \mathrm{DKG}$ \\
\hline SHS 2003 & GLU & PMS & + & - & - & - \\
\hline 2006 & & plus & + & - & - & - \\
\hline 2008 & & DCPIP & + & - & - & - \\
\hline SHS 2003 & DGA & PMS & & + & - & - \\
\hline 2006 & & plus & & + & - & - \\
\hline 2008 & & DCPIP & & + & - & - \\
\hline SHS 2003 & $2 \mathrm{KDG}$ & PMS & - & & - & + \\
\hline 2006 & & plus & - & & - & + \\
\hline 2008 & & DCPIP & - & & - & + \\
\hline SHS 2003 & $5 \mathrm{KDG}$ & PMS & - & - & & - \\
\hline 2006 & & plus & - & - & & - \\
\hline 2008 & & DCPIP & - & - & & - \\
\hline
\end{tabular}

a GLU, D-glucose; DGA, D-gluconate; 2KDG, 2-keto-D-gluconate; 5KDG, 5-keto-D-gluconate.

${ }^{b}$ PMS, phenazine methosulfate; DCPIP, 2,6-dichlorophenol indophenol.

c + , detected; --, not detected. 
gluconate was produced slightly from Dgluconate in the soluble fractions of the cell extracts of all three strains in the presence of $1.0 \mathrm{~mm} \mathrm{KCN}$.

Dehydrogenating activities in the soluble and particulate fractions

To clarify the location of the enzyme(s) responsible for the oxidation of $\mathrm{D}$-glucose to 25DKG, the soluble and particulate fractions of the cell extracts prepared from the above three representative strains, SHS 2003, SHS 2006 and SHS 2008, were further examined. Table III shows the results obtained when PMS plus DCPIP was used as electron acceptors. More than $90 \%$ of the D-glucose dehydrogenating activities, more than $82 \%$ of the D-gluconate dehydrogenating activities and more than $80 \%$ of the 2-keto-D-gluconate dehydrogenating activities of the cell extracts of the three strains were found in the respective particulate fractions.

Table III. Distribution of Activities of

D-GLuCOSE Dehydrogenation (GLDH), D-Gluconate Dehydrogenation, (GADH) and

2-KetO-D-GLUCONATE DeHYdROGENATION (2KDDH) IN CELL ExTRaCTS OF THF RePRESENTATIVE Strains, SHS 2003, SHS 2006 AND SHS $2008^{a, b}$

\begin{tabular}{clrcc}
\hline & & \multicolumn{3}{c}{ Distribution of activities (\%) } \\
\cline { 3 - 5 } Strain & Fraction & GLDH & GADH & 2KDDH \\
\cline { 3 - 5 } SHS 2003 & Soluble & 2.5 & 8.0 & 17.8 \\
& Particulate & 97.5 & 92.0 & 82.2 \\
\hline \multirow{2}{*}{ SHS 2006 } & Soluble & 3.4 & 15.0 & 6.8 \\
& Particulate & 96.6 & 85.0 & 93.2 \\
\hline SHS 2008 & Soluble & 9.9 & 17.6 & 19.4 \\
& Particulate & 90.1 & 82.4 & 80.6 \\
\hline
\end{tabular}

a Total activities of GLDH, GADH and $2 \mathrm{KDDH}$ in the cell extracts (Units/mi): $37.76,47.82$ and 21.08 for strain $2003 ; 17.60,14.48$ and 29.38 for strain 2006; and $9.04,20.86$ and 22.56 for strain 2008 . One unit was defined as the amount of enzyme reducing $1 \mu \mathrm{mol}$ of 2,6-dichlorophenolindophenol per minute at $28^{\circ} \mathrm{C}$.

b The concentrations of protein in the cell extracts $(\mathrm{mg} / \mathrm{ml}) ; 15.80$ for strain $2003,17.22$ for strain 2006 and 11.06 for strain 2008 .

\section{DISCUSSION}

Ninety-six bacterial strains that produced more or less Ca-25DKG from $25 \%$ (w/v) Dglucose in baffled flasks were isolated from 235 soil, fruit and vegetable samples. Using a few strains chosen from among them, we studied a number of fermentation parameters in order to optimize the Ca-25DKG production. The parameters included inoculum size, aeration, timing of transfer and timing of $\mathrm{D}$-glucose feeding. The most effective results as to $\mathrm{Ca}$ $25 \mathrm{DKG}$ production were obtained by feeding D-glucose as described previously. ${ }^{1)}$ Under these conditions, 42 strains among the 96 strains produced CA-25DKG from $30 \%(\mathrm{w} / \mathrm{v})$ D-glucose with excellent yields of more than $70 \mathrm{~mol}^{\%} \%$ in $1-1$ fermentors containing a simple medium, e.g., D-glucose, corn steep liquor, $\mathrm{KH}_{2} \mathrm{PO}_{4}, \mathrm{MgSO}_{4} \cdot 7 \mathrm{H}_{2} \mathrm{O}, \mathrm{CaCO}_{3}$ and tap water. The fermentations were all completed within $40 \mathrm{hr}$.

Interestingly, all of the 42 strains are small rod-shaped, gram-negative, non-spore-forming and facultatively anaerobic bacteria, and can be classified taxonomically into three groups. Representative strains, SHS 2003, SHS 2006 and SHS 2008, were identified as members of the genus Erwinia as described under RESUlTS. The ability of microorganisms to oxidize D-glucose to $25 \mathrm{DKG}$ has been reported for gram-negative and strictly aerobic bacteria belonging to the genera Acetobacter, ${ }^{2 \sim 4)}$ Gluconobacter $^{5}$ and Acetomonas. ${ }^{6)}$ Since our isolates were able to grow under anaerobic conditions but could not grow at $\mathrm{pH} 4.5$, they could not be assigned as members of the genus Acetobacter or Gluconobacter. In addition, the $\mathrm{G}+\mathrm{C}$ contents of our representative strains $(46.3$ to 48.7 $\mathrm{mol} \%$ ) were lower than those of the above two genera ( 51 to $64 \mathrm{~mol} \%)^{25,26)}$ Recently, Acetomones albosesamae (Wakisaka) ATCC No. $\left.21998^{6}\right)$ has been listed as Erwinia herbicola in the ATCC catalogue. ${ }^{14)}$ Its $\mathrm{G}+\mathrm{C}$ content $(55.5 \mathrm{~mol} \%)$, however, is higher than those of our isolates. Bernaerts and De Ley ${ }^{27}$ also reported that a few strains of Chromobacte- 
rium (gram-negative and facultatively anaerobic) produced small amounts of $25 \mathrm{DKG}$ from D-gluconate. Our isolates, however, differ in oxidase activity and $\mathrm{G}+\mathrm{C}$ content, which are positive and 50 to $68 \mathrm{~mol} \%$, respectively, for Chromobacterium. ${ }^{28}$ ) From these differences, it seems that bacteria capable of producing $25 \mathrm{DKG}$ in high concentrations with high yields from D-glucose are usually small rod-shaped, gram-negative, non-sporeforming and facultatively anaerobic bacteia, Erwinia species, with $\mathrm{G}+\mathrm{C}$ contents, 46.3 to $48.7 \mathrm{~mol} \%$, lower than those of the known Ewinia species (50 to $57 \mathrm{~mol} \%)^{18}$ )

The oxidation of D-glucose to $25 \mathrm{DKG}$ via D-gluconate and 2-keto-D-gluconate has been reported for $A$. melanogenum MA $6.2,{ }^{3)} P$. albosesamae ${ }^{7)}$ and pigment-producing strains of Gluconobacter. ${ }^{5)}$ Another pathway of Dglucose to $25 \mathrm{DKG}$ via D-gluconate and 5keto-D-gluconate has been proposed for $A$. melanogenus ATCC 9937.4) All our isolates accumulated D-gluconate and 2-keto-Dgluconate as intermediate products from Dglucose, whereas no 5 keto-D-gluconate could be detected in the culture broth throughout their cultivation. To clarify the metabolic pathway for D-glucose, the reaction products with the cell extracts of the three representative strains were analyzed in the presence of electron acceptors. D-Gluconate was produced from D-glucose, 2-keto-D-gluconate from D-gluconate and $25 \mathrm{DKG}$ from 2keto-D-gluconate. However, 5-keto-D-gluconate was not produced from D-gluconate, nor 25DKG from 5-keto-D-gluconate. These results suggested that our isolates oxidize D-glucose to $25 \mathrm{DKG}$ via D-gluconate and 2-keto-D-gluconate, i.e., via a pathway similar to that in $A$. melanogenum MA 6.2, $P$. albosesamae and pigment-producing strains of Gluconobacter.

In pigment-producing strains of Gluconobacter, ${ }^{5}$ 25DKG production has been reported to be catalyzed by membrane-bound enzymes (particulate enzymes). In our three representative strains, most activities of enzyme(s) responsible for the dehydrogenation of D-glucose, D-gluconate and 2-keto-Dgluconate were also found in the particulate fractions, thus indicating that the enzyme(s) are membrane-bound.

Acknowledgments. We wish to thank Dr. Tahiko Honjo, former director of our department, for his continued interest and encouragement, and Professor Shuichi Aiba, Osaka University, for the valuable discussions during the course of this work. We also wish to thank Mr. Masahiro Tanimoto for his excellent assistance in the screening work.

\section{REFERENCES}

1) T. Sonoyama, H. Tani, K. Matsuda, B. Kageyama, M. Tanimoto, K. Kobayashi, S. Yagi, H. Kyotani and K. Mitsushima, Appl. Environ. Microbiol., 43, 1064 (1982).

2) T. C. Crawford and S. A. Crawford, Adv. Carbohydrate Chem. Biochem., 37, 79 (1980).

3) H. Katznelson, S. W. Tanenbaum and E. L. Tatum, J. Biol. Chem., 204, 43 (1953).

4) R. M. Stroshane and D. Perlmann, Biotechnol. Bioeng., 19, 459 (1977).

5) E. Shinagawa, T. Chiyonobu, O. Adachi and $M$ Ameyama, Agric. Biol. Chem., 40, 475 (1976).

6) T. Sonoyama, H. Tani, B. Kageyama, K. Kobayashi, T. Honjo and S. Yagi, U. S. Patent 3,959,076, 1976.

7) Y. Wakisaka, Agric. Biol. Chem., 28, 369 (1964).

8) Y. Wakisaka, Agric. Biol. Chem., 28, 819 (1964).

9) H. Mollering and H. U. Bergmeyer, "Methods of Enzymatic Analysis," Vol. 3, 2nd English Ed., ed. by H. U. Bergmeyer, Academic Press Inc., New York, 1974, p. 1243.

10) H. J. Conn, J. W. Bartholomew and M. W. Jennison, "Manual of Microbiological Methods," ed. by M. J. Pelczar (editor-in-chief), McGraw-Hill Book Co., Inc., New York, 1957, p. 10.

11) H. J. Conn, M. W. Jennison and O. B. Weeks, "Manual of Microbiological Methods," ed. by M. J. Pelczar (editor-in-chief), McGraw-Hill Book Co., Inc., New York, 1957, p. 140.

12) R. N. Doetsh, "Manual of Methods for General Bacteriology," ed. by P. Gerhardt, American Society for Microbiology, Washington, DC, 1981 , p. 21.

13) R. N. Smibert and N. R. Krieg, "Manual of Methods for General Bacteriology," ed. by P. Gerhardt, American Society for Microbiology, Washington, DC, 1981, p. 409.

14) American Type Culture Collection, "Catalogue of Strain I," 15th Ed., Maryland, 1982, p. 601.

15) J. Hillier, G. Knaysi and R. F. Baker, J. Bacteriol., 56, 569 (1948). 
16) D. W. Dye, N. Z. J. Sci., 11, 590 (1968).

17) C. Shaw and R. H. Clark, J. Gen. Microbiol., 13, 155 (1955).

18) R. A. Lelliott and R. S. Dickey, "Bergey's Manual of Systematic Bacteriology," Vol. 1, ed. by N. R. Krieg and J. G. Holt, The Williams and Wilkins, Baltimore, 1984, p. 469.

19) A. M. Paton, Nature, 183, 1812 (1959).

20) Y. Yamada, K. Aida and T. Uemura, J. Gen. Appl. Microbiol., 15, 181 (1969).

21) J. Marmur and P. Doty, J. Mol. Biol., 5, 109 (1962).

22) C. L. Schidkraut, J. Marmur and P. Doty, J. Mol. Biol., 4, 430 (1962).

23) O. H. Lowry, N. J. Rosebrough, A. L. Farr and R. J. Randall, J. Biol. Chem., 193, 265 (1951).

24) D. J. Brenner, "Bergey's Manual of Systematic
Bacteriology," Vol. 1, ed. by N. R. Krieg and J. G. Holt, The Williams and Wilkins, Baltimore, 1984, p. 408.

25) J. De Ley and J. Swings, "Bergey's Manual of Systematic Bacteriology," Vol. 1, ed. by N. R. Krieg and J. G. Holt, The Williams and Wilkins, Baltimore, 1984, p. 275.

26) J. De Ley, J. Swings and F. Gossele, "Bergey's Manual of Systematic Bacteriology," Vol. 1, ed. by N. R. Krieg and J. G. Holt, The Williams and Wilkins, Baltimore, 1984, p. 268.

27) M. Bernaerts and J. De Ley, Antonie van Leeuwenhoek, 37, 185 (1971).

28) P. H. A. Sneath, "Bergey's Manual of Systematic Bacteriology," Vol. 1, ed. by N. R. Krieg and J. G. Holt, The Williams and Wilkins, Baltimore, 1984, p. 580 . 